\title{
Pedati Model Online Learning in University
}

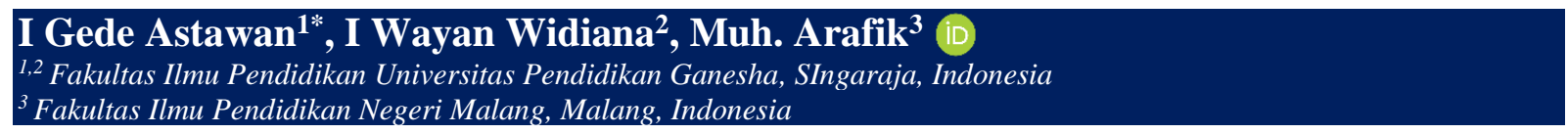

\section{A R T I C L E I N F O}

Article history:

Received September 10, 2021

Revised September 11, 2021

Accepted October 12, 2021

Available online November 25, 2021

Kata Kunci:

Studi Evaluasi, Pembelajaran

Daring, Model Pedati

Keywords:

Evaluation Study, Online Learning, Pedati Model

DOI:

https://dx.doi.org/10.23887/jet.v5i4. 41124

\begin{abstract}
A B S T R A K
Sejak pandemi Covid 19 melanda dunia, berbagai perubahan terjadi pada dunia pendidikan. Guru dituntut untuk dapat mengembangkan pembelajaran online agar kegiatan pembelajaran dapat berjalan lancer. Tujuan penelitian ini adalah menganalisis efektivitas pembelajaran daring di peruruan tinggi. Subjek penelitian adalah dosen yang berjumlah 22 orang. Objek penelitian meliputi efektivitas program pembelajaran daring ditinjau dari segi konteks, masukan, proses, dan produk. Pendekatan yang digunakan pada penelitian ini adalah pendekatan evaluatif. Desain model penelitian yang digunakan adalah model evaluasi CIPP (Context, Input, Process and Product Evaluation Model). Data dianalisis secara statistik deskriptif dengan menghitung persentase. Selanjutnya, data dianalisis dengan rumus T-Score. Tingkat efektivitas pembelajaran daring dianalisis melalui kuadran model "Glickman". Hasil analisis data menunjukkan bahwa pembelajaran daring di PGSD ditinjau dari segi konteks, secara deskriptif tergolong sangat baik, dengan persentase keefektifan sebesar 18,18\%. Pembelajaran daring di PGSD Undiksha ditinjau dari segi masukan, secara deskriptif sangat baik, dengan persentase keefektifan sebesar 0\%. Pembelajaran daring di PGSD Undiksha ditinjau dari segi proses, secara deskriptif tergolong sangat baik, dengan persentase keefektifan -9,09\%. Pembelajaran daring di PGSD Undiksha ditinjau dari segi produk, secara deskriptif tergolong sangat baik, dengan dengan persentase keefektifan sebesar 18,18\%. Dapat disimpulkan bahwa pembelajaran daring yang telah diselenggarakan sangat baik dan efektif
\end{abstract}

\section{A B S T R A C T}

Since the COVID-19 pandemic hit the world, various changes have occurred in the world of education. Teachers are required to be able to develop online learning so that learning activities can run smoothly. The purpose of this study was to analyze the effectiveness of online learning in universities. The research subjects were lecturers totalling 22 people. The research object includes the effectiveness of online learning programs in terms of context, input, process, and product. The approach used in this study is evaluative. The research model design used is the CIPP evaluation model (Context, Input, Process and Product Evaluation Model). The data were analyzed descriptively by calculating the percentage. Next, the data were analyzed by the T-Score formula. The level of effectiveness of online learning was analyzed through the quadrant of the "Glickman" model. The results of data analysis showed that online learning in PGSD, in terms of context, descriptively classified as very good, with an effectiveness percentage of $18.18 \%$. Online learning at PGSD Undiksha in terms of input, descriptively is very good, with an effectiveness percentage of $0 \%$. In terms of process, online learning at PGSD Undiksha is descriptively classified as very good, with an effectiveness percentage of $-9.09 \%$. In terms of products, online learning at PGSD Undiksha descriptively is classified as very good, with an effectiveness percentage of $18.18 \%$. It can be concluded that the online learning that has been held is excellent and effective.

This is an open access article under the CC BY-SA license. Copyright @ 2021 by Author. Published by Universitas Pendidikan Ganesha.

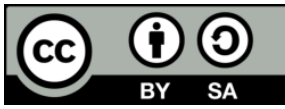

\section{INTRODUCTION}

At the beginning of 2020, the world was shocked by the spread of a virus outbreak known as Coronavirus Diseases 2019 (Covid 19). The coronavirus was allegedly first discovered in China, which has now spread throughout the world. The World Health Organization (WHO) has declared Covid 19 a pandemic. It is because of the broad impact caused by Covid 19 (Hincal \& Alsaadi, 2021; Kadafi et al., 2021; Yulia, 2020). Since the COVID-19 pandemic hit the world, various changes have occurred in various areas of life. The world must adapt to its various activities (Dhawan, 2020; Maulana, 2021). The world of education has also not been spared the impact of the COVID-19 pandemic (Ali, 2020; Saha et al., 2021). Early childhood education, primary and secondary education, and higher education are expected to adapt to continue to provide good services in the 
field of education (Browning et al., 2021; Satyawan et al., 2021). Higher education has more responsibilities than previous levels because it has the tri dharma of higher education (Ramkissoon et al., 2020; Satyawan et al., 2021). Implementing the tri dharma of higher education faces its challenges in the midst of this new normal, both in education and teaching, research and community service. Universities are required to be creative and innovative to continue to carry out their tri dharma activities, especially education/learning in this pandemic condition (Chou, 2013; Odriozola-González et al., 2020). In this case, the Ministry of Education and Culture government has issued a policy in education to prevent the spread of COVID-19 regarding Online Learning and Working from Home (Permata \& Bhakti, 2020; Sugiarto, 2020). It aims to prevent the spread of Covid-19 (Dewa et al., 2020; Herliandry et al., 2020). Education units are directed to continue to carry out learning packaged online. Learning from home through online/distance learning is implemented to provide meaningful learning for students (Hutauruk \& Sidabutar, 2020; Saragih et al., 2020). All learning activities are currently conducted by conducting distance learning and suggesting students study from their homes (Hanifah Salsabila et al., 2020; Mustakim, 2020; Ro'fah et al., 2020).

In line with this government policy, Ganesha University of Education (Undiksha) fully supports and follows up on various policies regarding the extension of working from home for all Undiksha BLU employees. The odd semester and even semester of the 2020/2021 academic year is also set to carry out complete online learning. PGSD, as part of Undiksha under the auspices of the Faculty of Education, is committed to implementing quality online learning. 100\% of learning is carried out online through Undiksha e-learning. PGSD has developed its standardized online learning in the PGSD Study Program to ensure quality in education and learning. All PGSD lecturers use online learning with the PEDATI model. PEDATI is an acronym for Learn, Experience, Apply, Evaluate (Chaeruman, 2017). Online learning in the PGSD Study Program uses the Learning Management System (LMS) or e-learning provided by Undiksha. However, the management has been set so that it becomes the standard for every lecturer. These standards include the number of meetings 16 times, including UTS and UAS. Each meeting contains one discussion topic, so there are 14 discussion topics. During one semester, six assignments must be done by students in e-learning. Every two weeks, lectures are held face-toface (video conference). Online learning activities are currently ongoing.

The concept of online learning was developed in Indonesia before the pandemic with the term Distance Learning (Laksana et al., 2019; Mutohhari et al., 2021). Distance learning began to appear at the end of the 20th century. At the beginning of the 21 st century, PJJ became one of the practical learning methods (Lenar et al., 2014). Distance Learning is defined as a learning process that does not take into account space and time, has an independent nature for developing students using methods and media in learning activities (Kor et al., 2014; Satyawan et al., 2021). Online learning is one of the best solutions to overcome learning problems in the covid19 pandemic (Heng \& Sol, 2020; Saha et al., 2021; Satyawan et al., 2021). Previous research findings state that online learning will help students learn remotely (Asmuni, 2020; Lorenza \& Carter, 2021). Other research findings also state that online learning will make it easier for students to study anywhere (Alavudeen et al., 2021; Cahyadi, 2020; Laksana, 2020). Online learning can be applied during the covid-19 pandemic to make it easier for students to learn. It is exciting to conduct an evaluation study on the effectiveness of online learning in the PGSD Study Program. The effectiveness of online learning can be viewed in terms of context, input, process, and product. In addition, it is crucial to research the obstacles faced and solutions made in implementing online learning. The purpose of this study was to analyze the effectiveness of online learning in universities. It is hoped that this research can provide solutions to problems regarding online learning.

\section{METHOD}

This research was conducted at the Elementary School Teacher Education Study Program, Ganesha University of Education. The subjects in this study were PGSD lecturers who taught the even semester courses for the 2020/2021 academic year, totalling 22 people. The research approach used in this study is evaluative because the researcher wants to evaluate an online learning program/activity. By using this evaluative research, researchers can collect, analyze and use the information to assess the work performance of online learning programs. In addition, researchers can provide recommendations for improvement/improvement of the evaluated learning program with evaluative research (Lukum, 2015). The research model design used is the CIPP evaluation model (Context, Input, Process and Product Evaluation Model). The CIPP model consists of four types of evaluation, namely context evaluation, input evaluation, process evaluation and product evaluation (Junanto \& Kusna, 2018). Using the CIPP model in this study is because the CIPP model is very appropriate and suitable for evaluating learning programs. The methods used to collect data are observation and questionnaires. The instrument used to collect data is a questionnaire. The data collected in this study include: 1) the implementation of online learning in terms of context, 2) the implementation of online learning in terms of input, 3 ) the implementation of online learning in terms of the process, and 4) the implementation of online learning in terms of products. Data were collected using a questionnaire that had been given to lecturers at PGSD. Data were 
analyzed using descriptive statistical analysis techniques by calculating the percentage of guidelines used to provide meaning and decision making on the quality of online learning are presented in Table 1.

Table 1. Guidelines for Conversion of Five-Scale Online Learning Programs

\begin{tabular}{ccc}
\hline No. & Score Range (\%) & Qualification \\
\hline 1 & $90,00-100,00$ & Very good \\
2 & $75,00-89,00$ & Well \\
3 & $65,00-74,00$ & Enough \\
4 & $55,00-64,00$ & Not good \\
5 & $0,00-54,00$ & Not very good \\
\hline
\end{tabular}

Data analysis on each context variable, input, process, and product is directed to applying the standard curve. Data above or to the right of the reception area is marked with a positive (+) sign, whereas data on the left or below the reception area is marked with a negative sign (-). To determine the score for each variable, it is calculated using the T-Score. If $\mathrm{T}>50$, the direction is positive or high $(+)$, and if $\mathrm{T}$ is 50 , the direction is negative or low (-). Meanwhile, the final results of each context variable, input, process, and product are calculated by adding up the positive (+) and negative (-) scores. If the number of positive scores is more, the result is positive $(+)$, and vice versa. If the number of positive scores is less than or equal to the number of negative scores, the result is negative (-). In answering the problem of the effectiveness of the implementation of online learning programs in PGSD, the T-Score is used. The classification is converted according to the Glickman type. To determine the effectiveness of the implementation of online learning programs using a communicative-integrative approach, an analysis of the context, input, process, and product variables was carried out through quadrant analysis of the "Glickman" model (1981), which was divided into four quadrants.

\section{RESULT AND DISCUSSION}

\section{Result}

In terms of context, online context learning in PGSD includes several aspects: the availability of a legal basis, curriculum, stakeholder support, lecturer competence, and lecturer attitudes. Overall, in terms of context, online learning in PGSD reached an average score of 114.18, which was in the very good category. A total of 21 people $(95.45 \%)$ were in the very good category, and 1 person $(4.55 \%)$ was in the good category. Next, we continue to calculate the T-Scor to see the effectiveness of the program. Online learning in PGSD in terms of input includes several aspects, namely students, management, and infrastructure. In general, online learning at PGSD regarding inputs reached an average score of 87.14, which was in the very good category. A total of 19 people $(86.36 \%)$ said it was very good, and as many as three people (13.64\%) said it was good. Next, it is continued to calculate the T-Scor to see the effectiveness of the program. Online learning in PGSD is viewed in terms of processes related to the preparation and implementation of online learning. The quality of online learning in PGSD in terms of the process reached an average score of 54.41 in the very good category. A total of 21 people $(95.45 \%)$ said it was very good, and as many as one person $(4.45 \%)$ said it was good. Next, we continue to calculate the T-Scor to see the effectiveness of the program. Online learning in PGSD is viewed in terms of products related to learning outcomes after online learning is carried out. The results of online learning at PGSD regarding products reached an average score of 41.86 in the very good category. A total of 18 people $(86.36 \%)$ said it was very good, and as many as four people $(13.64 \%)$ said it was good. Next, we continue to calculate the T-Scor to see the effectiveness of the program. The recapitulation of the calculation results of context variables, inputs, processes, and products is presented in Table 2.

Table 2. Recapitulation of Context, Input, Process, and Output Variavel Calculation Results with T-score

\begin{tabular}{lcccc}
\hline \multirow{2}{*}{ Variable } & \multicolumn{2}{c}{ Frequency } & \multirow{2}{*}{ Results } & \multirow{2}{*}{ Information } \\
\cline { 2 - 3 } & F+ & F- & & Positive \\
Konteks & 13 & 9 & + & Positive \\
Input & 11 & 11 & + & Negative \\
Proses & 10 & 12 & - & Positive \\
Output & 13 & 9 & + & Positive, Positive, Negative, Positive \\
\hline
\end{tabular}

Based on table 2, the recapitulation of the calculation results of context variables, input, process, and output with a t-score, obtained for the context component in the positive $(+)$ category, for the input component in 
the positive $(+)$ category, for the process component in the harmful category (-), and the output component is categorized as positive (+). After being consulted with the Glikman quadrant, implementing the bold learning program at PGSD was qualified to be quite effective. The findings of this study revealed that the learning program in PGSD was implemented quite effectively. It shows that the courageous learning carried out by the PGSD study program during covid, especially in the even semester of the 2020/2021 academic year, was carried out well.

\section{Discussion}

Of the four components of CIPP as an approach in conducting evaluation studies, three components, namely context, input, and product, are positive (+). Meanwhile, the process component is still negative (-). It means that the availability of legal foundations, curriculum, stakeholder support, lecturer competence, and lecturer attitudes in online learning is very good regarding aspects of students, management, and adequate infrastructure. The results of student learning outcomes as aspects of the product in this study have been achieved well. Good learning is shown through the learning outcomes obtained by students (Alhefnawi, 2021; Satyawan et al., 2021). However, the online learning process seems to need improvement. As it is known, online learning is carried out using internet facilities (Alhefnawi, 2021; Hogan \& Devi, 2019; Satyawan et al., 2021). Educators and students do not meet conventionally face-to-face (Kumari et al., 2020; Roling et al., 2020). This condition demands the independence of student learning. Students must have a high awareness of learning and actively discuss both at LMS and during video conferences (Bervell \& Arkorful, 2020; Hussin et al., 2018; Mutohhari et al., 2021). It is a challenge to motivate students to stay disciplined and study hard. Lecturer activity facilitating learning is essential in providing feedback at LMS and during video conferences (Bervell et al., 2020; Sakova \& Chevereva, 2021; Zabolotniaia et al., 2020). The results of this study are in line with research conducted by previous researchers. The implementation of learning which includes the requirements for implementing learning and learning activities, after being analyzed with the CIPP model, is declared quite effective (Bhakti, 2017; Magdalena et al., 2020). The online learning system program in the PMIPA FKIP Unila environment as a whole is quite good so that it can be continued (Riyanda et al., 2020). Since the outbreak, the implementation of online learning in Higher Education has been going well (Mahnun, 2018; Sugiarto, 2020). University managers in the Covid-19 era take the policies to carry out online learning where deemed appropriate, according to the needs and situations (Chou, 2013; Satyawan et al., 2021).

In terms of input, both in terms of the quality of lecturers and students, they are quite competent in managing online learning. The substance of the material delivered is not reduced in the slightest when compared to face-to-face classes. However, the problems that arise are from the non-technical side. Where network issues and data packet costs are a concern for students (Arizona et al., 2020; Yudiawan, 2020). Online learning in elementary schools during the COVID-19 pandemic was able to increase knowledge, skills, mastery of technology, autonomy, creativity, independence of students and show the readiness of school institutions, both teachers and facilities to carry out distance learning (Hanifah Salsabila et al., 2020; Huang, 2020; Sujarwo et al., 2020). Online learning is less than optimal in increasing students' ability, especially non-academic ones such as character building, interaction effectiveness in learning, complete learning, personality enhancement, giving motivation oriented to exemplary life and the accuracy of evaluation of increasing student abilities (Waruwu, 2020). The findings of this study imply that online learning should be well prepared in terms of context, input, and process to produce sound output. In the online learning process, it should be packaged so that students can still learn optimally. Design online learning to be packaged differently from offline learning. In offline learning, learning design can consider interactions between students and lecturers carried out and observed directly (Hogan \& Devi, 2019; Satyawan et al., 2021). Meanwhile, online learning is challenging to do. Therefore, giving structured assignments to be a concern so that it can help students learn. Furthermore, these tasks should be cross-checked and given feedback. The model that can be chosen in online learning is the flipped classroom. Tasks are given first before virtual face-to-face learning is carried out. During virtual face-to-face, these tasks are discussed intensively.

\section{CONCLUSION}

The online learning program in PGSD, in terms of context, descriptively is classified as very good. The online learning program at PGSD in terms of input descriptively is very good. The online learning implementation program at PGSD is viewed in terms of process; descriptively, it is classified as very good. The online learning program at PGSD, in terms of product descriptively, is classified as very good. During online learning, it is recommended for students to increase awareness of independent learning, actively discuss both at LMS and during video conferences. 


\section{REFERENCES}

Alavudeen, S. S., Easwaran, V., Mir, J. I., Shahrani, S. M., Ahmed Mohammed Almodeer Aseeri, A. A., Khan, N. A., \& Asiri, A. A. (2021). The influence of COVID-19 related psychological and demographic variables on the effectiveness of e-learning among health care students in the southern region of Saudi Arabia. Saudi Pharmaceutical Journal. https://doi.org/10.1016/j.jsps.2021.05.009.

Alhefnawi, M. A. M. (2021). Assessing the efficacy of online handouts and active lectures in learning outcomes at the engineering undergraduate level. Ain Shams Engineering Journal, 40. https://doi.org/10.1016/j.asej.2021.02.012.

Ali, W. (2020). Online and Remote Learning in Higher Education Institutes: A Necessity in light of COVID-19 Pandemic. Higher Education Studies, 10(3), 16-25. https://doi.org/10.5539/hes.v10n3p16.

Arizona, K., Abidin, Z., \& Rumansyah, R. (2020). Pembelajaran Online Berbasis Proyek Salah Satu Solusi Kegiatan Belajar Mengajar Di Tengah Pandemi Covid-19. Jurnal Ilmiah Profesi Pendidikan, 5(1). https://doi.org/10.29303/jipp.v5i1.111.

Asmuni, A. (2020). Problematika Pembelajaran Daring di Masa Pandemi Covid-19 dan Solusi Pemecahannya. Jurnal Paedagogy, 7(4), 281. https://doi.org/10.33394/jp.v7i4.2941.

Bervell, B., \& Arkorful, V. (2020). LMS-enabled blended learning utilization in distance tertiary education: establishing the relationships among facilitating conditions, voluntariness of use and use behaviour. International Journal of Educational Technology in Higher Education, 17(1), 6. https://doi.org/10.1186/s41239-020-0183-9.

Bervell, B., Nyagorme, P., \& Arkorful, V. (2020). LMS-Enabled Blended Learning Use Intentions among Distance Education Tutors: Examining the Mediation Role of Attitude Based on Technology-Related Stimulus-Response Theoretical Framework (TR-SR-TF). Contemporary Educational Technology, 12(2), ep273. https://doi.org/10.30935/cedtech/8317.

Bhakti, Y. B. (2017). Bhakti, Y.B. (2017). Evaluasi Program Model CIPP Pada Proses Pembelajaran IPA. JIPFRI: Jurnal Inovasi Pendidikan Fisika Dan Riset Ilmiah, I(2). https://doi.org/10.30599/jipfri.v1i2.109.

Browning, M. H. E. M., Larson, L. R., Sharaievska, I., Rigolon, A., McAnirlin, O., Mullenbach, L., Cloutier, S., Vu, T. M., Thomsen, J., Reigner, N., Metcalf, E. C., D’Antonio, A., Helbich, M., Bratman, G. N., \& Alvarez, H. O. (2021). Psychological impacts from COVID-19 among university students: Risk factors across seven states in the United States. PloS One, 16(1), e0245327. https://doi.org/10.1371/journal.pone.0245327.

Cahyadi, A. (2020). Covid-19 Outbreak and New Normal Teaching in Higher Education: Empirical Resolve from Islamic Universities in Indonesia. Dinamika Ilmu, 20(2), 255-266. https://doi.org/10.21093/di.v20i2.2545.

Chaeruman, U. A. (2017). PEDATI, Model Desain Sistem Pembelajaran Blended. Direktorat Pembelajaran Kementrian Riset, Teknologi dan Pendidikan Tinggi.

Chou, P.-N. (2013). Students Perceptions Of Success In The Online Graduate-Level Classes: A Self-Directed Learning Perspective. Contemporary Issues in Education Research (CIER), 6(1), 115. https://doi.org/10.19030/cier.v6i1.7610.

Dewa, E., Maria Ursula Jawa Mukin, \& Oktavina Pandango. (2020). Pengaruh Pembelajaran Daring Berbantuan Laboratorium Virtual Terhadap Minat dan Hasil Belajar Kognitif Fisika. JARTIKA Jurnal Riset Teknologi Dan Inovasi Pendidikan, 3(2), 351-359. https://doi.org/10.36765/jartika.v3i2.288.

Dhawan, S. (2020). Online Learning: A Panacea in the Time of COVID-19 Crisis. Journal of Educational Technology Systems, 49(1), 5-22. https://doi.org/10.1177/0047239520934018.

Hanifah Salsabila, U., Irna Sari, L., Haibati Lathif, K., Puji Lestari, A., \& Ayuning, A. (2020). Peran Teknologi Dalam Pembelajaran Di Masa Pandemi Covid-19. Al-Mutharahah: Jurnal Penelitian Dan Kajian Sosial Keagamaan, 17(2), 188-198. https://doi.org/10.46781/al-mutharahah.v17i2.138.

Heng, K., \& Sol, K. (2020). Online learning during COVID-19: Key challenges and suggestions to enhance effectiveness. Cambodian Education Forum (CEF). https://doi.org/10.1371/journal.pone.0248758.

Herliandry, L. D., Nurhasanah, Suban, M. E., \& Heru, K. (2020). Pembelajaran Pada Masa Pandemi Covid-19. Jurnal Teknologi Pendidikan, 22(1), 65-70. https://doi.org/10.21009/jtp.v22i1.15286.

Hincal, E., \& Alsaadi, S. H. (2021). Stability analysis of fractional order model on corona transmission dynamics. Chaos, Solitons \& Fractals, 143, 110628. https://doi.org/10.1016/j.chaos.2020.110628.

Hogan, R., \& Devi, M. (2019). A synchronous pedagogy to improve online student success. International Journal of Online Pedagogy and Course Design, 9(3), 61-77. https://doi.org/10.4018/IJOPCD.2019070105.

Huang, Y. (2020). Research on Online Education in the Midst of the COVID-19 Pandemic. Journal of Advances in Education Research, 5(2), 125-137. https://doi.org/10.22606/jaer.2020.52005. 
Hussin, W. N. T. W., Harun, J., \& Shukor, N. A. (2018). Problem Based Learning to Enhance Students Critical Thinking Skill via Online Tools. Asian Social Science, 15(1), 14. https://doi.org/10.5539/ass.v15n1p14.

Hutauruk, A., \& Sidabutar, R. (2020). Kendala pembelajaran daring selama masa pandemi di kalangan mahasiswa pendidikan matematika: Kajian kualiatatif deskriptif. Journal of Mathematics Education and Applied, 02(01), 45-51. https://doi.org/10.36655/sepren.v2i1.364.

Junanto, S., \& Kusna, N. A. A. (2018). Evaluasi Program Pembelajaran di PAUD Inklusi dengan Model Context, Input, Process, and Product (CIPP). Journal of Disability Studies Inklusi, 2(2). https://doi.org/10.14421/ijds.050202.

Kadafi, A., Alfaiz, A., Ramli, M., Asri, D. N., \& Finayanti, J. (2021). The impact of islamic counseling intervention towards students' mindfulness and anxiety during the covid-19 pandemic. Islamic Guidance and Counseling Journal, 4(1), 55-66. https://doi.org/10.25217/igcj.v4i1.1018.

Kor, H., Aksoy, H., \& Eerbay, H. (2014). Comparison of the Proficiency Level of the Course Materials (Animations, Videos, Simulations, E-Books) Used In Distance Education. Procedia - Social and Behavioral Sciences, 141(1). https://doi.org/10.1016/j.sbspro.2014.05.150.

Kumari, A. T., Hemalatha, C. H., Subhani Ali, M., \& Naresh, R. (2020). Survey on Impact and Learning's of the Online Courses on the Present Era. Procedia Computer Science, 172, 82-91. https://doi.org/10.1016/j.procs.2020.05.167.

Laksana, D. N. L. (2020). The Implementation Of Online Learning During COVID-19 Pandemic: Student Perceptions In Areas With Minimal Internet Access. Journal of Education Technology, 4(4), 502-509. https://doi.org/10.23887/jet.v4i4.29413.

Laksana, D. N. L., Seso, M. A., \& Riwu, I. U. (2019). Content and Flores Cultural Context Based Thematic Electronic Learning Materials: Teachers and Students' Perception. European Journal of Education Studies, 5(9), 145-155. https://doi.org/10.5281/zenodo.2542946.

Lenar, S., Artur, F., Ullubi, S., \& Nailya, B. (2014). Problems And Decision In The Field Of Distance Education. Procedia - Social and Behavioral Sciences, 131. https://doi.org/10.1016/j.sbspro.2014.04.088.

Lorenza, L., \& Carter, D. (2021). International Journal of Educational Research Open Emergency online teaching during COVID-19: A case study of Australian tertiary students in teacher education and creative arts. International Journal of Educational Research Open, 2-2(May), 100057. https://doi.org/10.1016/j.ijedro.2021.100057.

Lukum, A. (2015). Evaluasi Program Pembelajaran IPA SMP Menggunakan Model Countenance Stake. Jurnal Penelitian Dan Evaluasi Pendidikan, 19(1), 25-37. https://doi.org/10.21831/pep.v19i1.4552.

Magdalena, I., Fauziyyah, B. S., Afiani, R., \& Fushilat, L. A. (2020). Inovasi Teknologi Dalam Pembelajaran Pada Masa Pandemi Covid-19 Di Mi Nurul Yaqin. Pensa: Jurnal Pendidikan Dan Ilmu Sosial, 2(3). https://ejournal.stitpn.ac.id/index.php/pensa/article/view/1017.

Mahnun, N. (2018). Implementasi Pembelajaran Online dan Optimalisasi Pengelolaan Pembelajaran Berbasis Online di Perguruan Tinggi Islam dalam Mewujudkan World Class University. IJIEM: Kajian Teori Dan Hasil Penelitian Pendidikan, 1(1), 29-36. https://doi.org/10.24014/ijiem.v1i1.5240.

Maulana, H. A. (2021). Psychological Impact of Online Learning during the COVID-19 Pandemic: A Case Study on Vocational Higher Education. Indonesian Journal of Learning Education and Counseling, 3(2), 130-139. https://doi.org/10.31960/ijolec.v3i2.833.

Mustakim, M. (2020). Efektivitas Pembelajaran Daring Menggunakan Media Online Selama Pandemi Covid-19 Pada Mata Pelajaran Matematika. Al Asma: Journal of Islamic Education, 2(1), 1-12. https://doi.org/10.24252/asma.v2i1.13646.

Mutohhari, F., Sudira, P., \& Nurtanto, M. (2021). Automotive Engineering Drawing Learning: Effective Online Learning Using Autocad Application. Journal of Education Technology, 5(2), 214-219. https://doi.org/10.23887/jet.v5i2.33197.

Odriozola-González, P., Planchuelo-Gómez, Á., Irurtia, M. J., \& de Luis-García, R. (2020). Psychological effects of the COVID-19 outbreak and lockdown among students and workers of a Spanish university. Psychiatry Research, 290. https://doi.org/10.1016/j.psychres.2020.113108.

Permata, A., \& Bhakti, Y. B. (2020). Keefektifan Virtual Class dengan Google Classroom dalam Pembelajaran Fisika Dimasa Pandemi Covid-19. JIPFRI (Jurnal Inovasi Pendidikan Fisika Dan Riset Ilmiah), 4(1), 27-33. https://doi.org/10.30599/jipfri.v4i1.669.

Ramkissoon, P., Belle, L. J., \& Bhurosy, T. (2020). Perceptions and experiences of students on the use of interactive online learning technologies in Mauritius. International Journal of Evaluation and Research in Education. https://doi.org/10.11591/ijere.v9i4.20692.

Riyanda, A. R., Herlina, K., \& Wicaksono, B. A. (2020). Evaluasi Implementasi Sistem Pembelajaran Daring Fakultas Keguruan dan Ilmu Pendidikan Universitas Lampung. Jurnal IKRA-ITH Humaniora, 4(1). https://journals.upi-yai.ac.id/index.php/ikraith-humaniora/article/view/669. 
Ro'fah, R., Hanjarwati, A., \& Suprihatiningrum, J. (2020). Is Online Learning Accessible During COVID-19 Pandemic? Voices and Experiences of UIN Sunan Kalijaga Students with Disabilities. In Nadwa (Vol. 14, Issue 1). https://doi.org/10.21580/nw.2020.14.1.5672.

Roling, G., Lutz, G., Edelhäuser, F., Hofmann, M., Valk-Draad, M. P., Wack, C., Haramati, A., Tauschel, D., \& Scheffer, C. (2020). Empathy, well-being and stressful experiences in the clinical learning environment. Patient Education and Counseling, 2019. https://doi.org/10.1016/j.pec.2020.04.025.

Saha, A., Dutta, A., \& Sifat, R. I. (2021). The mental impact of digital divide due to COVID-19 pandemic induced emergency online learning at undergraduate level: Evidence from undergraduate students from Dhaka City. Journal of Affective Disorders, 294(1). https://doi.org/10.1016/j.jad.2021.07.045.

Sakova, T. G., \& Chevereva, S. A. (2021). Fundamentals of Choosing an LMS Platform for Distance Learning. In Lecture Notes in Networks and Systems (pp. 348-353). https://doi.org/10.1007/978-3-030-609269_45.

Saragih, O., Sebayang, F. A. A., Sinaga, A. B., \& Ridlo, M. R. (2020). Kepuasaan Mahasiswa terhadap Pembelajaran Daring Selama Pandemi Covid-19. Journal of Language and Health, 7(3), 49-56. https://doi.org/10.37287/jlh.v1i2.383.

Satyawan, I. M., Wahjoedi, \& Swadesi, I. K. I. (2021). The Effectiveness of Online Learning Methods During the Covid-19 Pandemic. Journal of Education Technology, 5(2), 191-199. https://doi.org/10.2991/assehr.k.210203.093.

Sugiarto, A. (2020). Dampak Positif Pembelajaran Online Dalam Sistem Pendidikan Keperawatan Pasca Pandemi Covid 19. Jurnal Perawat Indonesia, 4(3), 432. https://doi.org/10.32584/jpi.v4i3.555.

Sujarwo, S., Sukmawati, S., Akhiruddin, A., Ridwan, R., \& Suharti Siradjuddin, S. S. (2020). An Analysis of University Students' Perspective On Online Learning in The Midst of Covid-19 Pandemic. Jurnal Pendidikan Dan Pengajaran, 53(2), 125. https://doi.org/10.23887/jpp.v53i2.24964.

Waruwu, M. (2020). Studi Evaluatif Implementasi Pembelajaran Daring Selama Pandemi Covid-19. Jurnal Administrasi Pendidikan, 27(2), 288-295. https://doi.org/10.17509/jap.v27i2.27081.

Yudiawan, A. (2020). Belajar Bersama COVID 19: Evaluasi Pembelajaran Daring Era Pandemi di Perguruan Tinggi Keagamaan Islam Negeri, Papua Barat. Al-Fikr: Jurnal Pendidikan Islam, 6(1). https://doi.org/10.32489/alfikr.v6i1.64.

Yulia, H. (2020). Online Learning to Prevent the Spread of Pandemic Corona Virus in Indonesia. ETERNAL (English Teaching Journal), 11(1). https://doi.org/10.26877/eternal.v11i1.6068.

Zabolotniaia, M., Cheng, Z., Dorozhkin, E., \& Lyzhin, A. (2020). Use of the LMS Moodle for an Effective Implementation of an Innovative Policy in Higher Educational Institutions. International Journal of Emerging Technologies in Learning (IJET), 15(13), 172. https://doi.org/10.3991/ijet.v15i13.14945. 